\title{
VOLUME CALCULATION OF RATS' ORGANS AND ITS APPLICATION IN THE VALIDATION OF THE VOLUME RELATION BETWEEN THE ABDOMINAL CAVITY AND THE HERNIAL SAC IN INCISIONAL HERNIAS WITH “LOSS OF ABDOMINAL DOMAIN"
}

Cálculo do volume de órgãos de ratos e sua aplicação na validação da relação de volumes entre a cavidade abdominal e o saco herniário em hérnias incisionais com "perda de domicílio"

Luz Marina Gonçalves de ARAÚJO, Leonardo Carvalho SERIGIOLLE, Helbert Minuncio Pereira GOMES, Daren Athiê Boy RODRIGUES, Carolina Marques LOPES, Pedro Luiz Squilacci LEME

From the Universidade Nove de Julho, São Paulo, SP, Brazil.
ABSTRACT - Background: The calculation of the volume ratio between the hernia sac and the abdominal cavity of incisional hernias is based on tomographic sections as well as the mathematical formula of the volume of the ellipsoid, which allows determining whether this is a giant hernia or there is a "loss of domain". As the images used are not exact geometric figures, the study of the volume of two solid organs of Wistar rats was performed to validate these calculations. Aim: To correlate two methods for determining the volume of the kidney and spleen of rats, comparing a direct method of observation of the volume with the mathematical calculation of this value. Methods: The volume of left kidney, geometrically more regular, and spleen, with its peculiar shape, of ten animals was established in cubic centimeters after complete immersion in water with the aid of a beaker graduated in millimeters. These values were compared with those obtained by calculating the same volume with a specific mathematical formula: $V=4 / 3$ $\times \pi \times(\mathrm{r} 1 \times \mathrm{r} 2 \times \mathrm{r} 3)$. Data were compared and statistically analyzed by Student's $\mathrm{t}$ test. Results: Although the average volume obtained was higher through the direct method $\left(1.13 \mathrm{~cm}^{3}\right.$ for the left kidney and $0.71 \mathrm{~cm}^{3}$ for the spleen) than the values calculated with the mathematical formula $\left(0.81 \mathrm{~cm}^{3}\right.$ and $\left.0.54 \mathrm{~cm}^{3}\right)$, there were no statistically significant differences between the values found for the two organs ( $p>0.05$ ). Conclusion: There was adequate correlation between the direct calculation of the volume of the kidney and spleen with the result of mathematical calculation of these values in the animals' studies. ventral. Intra-abdominal hypertension/ complications. Validation studies.
RESUMO - Racional: O cálculo da relação de volumes entre o saco herniário e a cavidade abdominal em hérnias incisionais é feito com base em cortes tomográficos e com a fórmula matemática do volume da elipsóide, permitindo determinar se a hérnia é gigante ou se há "perda de domicílio". Como as imagens utilizadas não são figuras geométricas exatas, foi realizado o estudo do volume de dois órgãos sólidos de ratos da linhagem Wistar, para validar estes cálculos. Objetivo: Correlacionar dois métodos para determinação do volume do rim e do baço de ratos, comparando um método direto de avaliação do volume com o cálculo matemático deste valor. Métodos: O volume do rim esquerdo, geometricamente mais regular, e do baço, com seu formato peculiar, de dez animais foram estabelecidos em centímetros cúbicos após imersão total em água, com auxílio de proveta graduada em milímetros; estes valores foram comparados com os obtidos através do cálculo do mesmo volume com fórmula matemática específica: $V=4 / 3 x$ $\pi \times(r 1 \times r 2 \times r 3)$. Os dados obtidos foram comparados e submetidos à análise estatística pelo teste t de Student. Resultados: Embora o volume médio obtido tenha sido maior com o método direto, $1,13 \mathrm{~cm}^{3}$ para o rim esquerdo e $0,71 \mathrm{~cm}^{3}$ para o baço, do que os valores calculados com a fórmula matemática, $0,81 \mathrm{~cm}^{3}$ e $0,54 \mathrm{~cm}^{3}$ respectivamente, não houve significância estatística entre as diferenças dos valores encontrados para os dois órgãos ( $p>0,05)$. Conclusão: Houve correlação adequada entre o cálculo direto do volume do rim e do baço com o resultado do cálculo matemático destes valores nos animais estudados.
DESCRTORES - Tamanho do órgão. Hérnia complicações. Estudos de validação.

\section{INTRODUCTION}

I ncisional hernias represent a challenge for its incidence, treatment complexity and high rates of recurrence after correction. The giant hernias are diseases of laborious surgical treatment, with significant morbidity and mortality, resulting in impairment to many activities and major socio-economic burden, requiring meticulous preoperative planning, as well as differentiated surgical techniques to avoid serious complications as injuries to the bowel during the dissection, the abdominal compartment syndrome ${ }^{3,5,17}$ and wound complications, which may compromise the result. The performance of these operations with the aid of laparoscopy and even robotics, demand significant resources and differentiated services, not affordable to patients of public health services, being options that are in early stages of development in the country ${ }^{1,2}$.

Four different problems are faced by the surgeon while planning the correction of a giant incisional hernia with conventional technique: first of all the identification 
of the "loss of domain"13,14, a condition which, if not properly identified, can have serious consequences during or shortly after operation such as abdominal compartment syndrome of extreme morbidity. The closure of the abdomen would be the second issue, since the viscera should not be in contact with the usual polypropylene synthetic prostheses, by development of adhesions, with risk of obstruction or intestinal fistulae ${ }^{4,23}$. Prostheses compatible with the abdominal cavity may be used, but its cost is high and as they haven't managed to completely avoid the appearance of intestinal adhesions, the tactics that employ the hernia sac, omentum, or "component separation" can be useful for this purpose. The third challenge is the reconstruction of the abdominal wall, to prevent recurrence, which is still very high; the various options described for this purpose show that there is no treatment that can be applied to all situations. Finally, the correction of dead space resulting from the large dermal-fat flaps, since the large hernias act as a skin expander, with the occurrence of collections and even infection postoperatively, situations often associated with recurrence ${ }^{18}$.

Both the U.S. and the European Consensus of hernias consider that the giant hernias are those in which the hernial orifice diameter is bigger than ten centimeters, but this criterion is flawed since it does not correctly access the overall size of the hernia and in clinical situations very large hernias with lower hernial orifices are often found, causing error in its sizing. In order to correct this distortion the calculation of the volume ratio between the hernia sac and abdominal cavity with the aid of usual transverse tomographic sections as well as sagittal sections are employed for three-dimensional evaluation of the hernia and abdomen. This allows a more accurate calculation, since if the volume ratio is higher than fifteen percent we will have a giant hernia, and if it is higher than $20 \%$, it is assumed a "loss of abdominal domain"; which implies that a whole preoperative planning needs to be established so that no abdominal compartment syndrome postoperatively will occur, bringing serious consequences and high mortality rates $13,17,26$.

If is consider that both the hernia sac and abdominal cavity are not exact geometric figures, a margin of error in the evaluation of these calculations may occur and the direct methods of volume analysis can not be applied in clinical practice. This study was proposed to confirm the validity of the calculation of this ratio of volumes, in which is evaluated the volume of the left kidney in rats, an organ that has a quite regular shape and also the spleen of the same animals that although it resembles the geometric figure studied, the ellipsoid, it has size differences between its upper and lower pole. Two calculation methods were compared, the direct evaluation of the volume of isolated organs, totally immersed in water and the same volume mathematically calculated in order to confirm that the results are similar, validating the use of mathematical calculation in clinical situations.

METHODS

The experiment was performed at the Universidade Nove de Julho, São Paulo, Brazil. The general rules for experimental research at the institution are strictly supervised and follow specific protocols ${ }^{10}$, but as the carcasses of animals that would be discarded were used, the approval of the Ethics Committee on Animal Use of the University was not necessary.

Ten dead Wistar rats used in practical classes of Disciplines of Health Sciences University, weighing between 250 and $300 \mathrm{~g}$ were used for this study, following the current concepts of "rational use of experimental animals" 15 .

Laparotomy with evisceration of carcasses was performed, the organs were removed, being just preserved the capsule and hilum of the left kidney and spleen, a reference point for the measurements required. The organs were weighed on a precision scale; with a caliper rule in major axis, the length, width and thickness were measured, always using the vessels of the hilum as a reference. After the measurements, the organs were totally immersed in water in a beaker with a millimeter scale, enabling assessment of the displacement of the water column by the analysis of the upper meniscus of this column, always performed by the same observer, allowing the measurement of the volume in cubic centimeters.

After determining the rays of length ( $r 1)$, width $(r 2)$ and thickness $(r 3)$ of each organ, the mathematical formula was applied to calculate the volume of the ellipsoid: $V=4 / 3 \times \pi \times$ $(r 1 \times r 2 \times r 3)^{26}$ (Figures 1 and 2). The results obtained by both methods were compared, being performed the statistical analysis with the Student's t test between both, the values of the spleen and the left kidney volume of the animals.
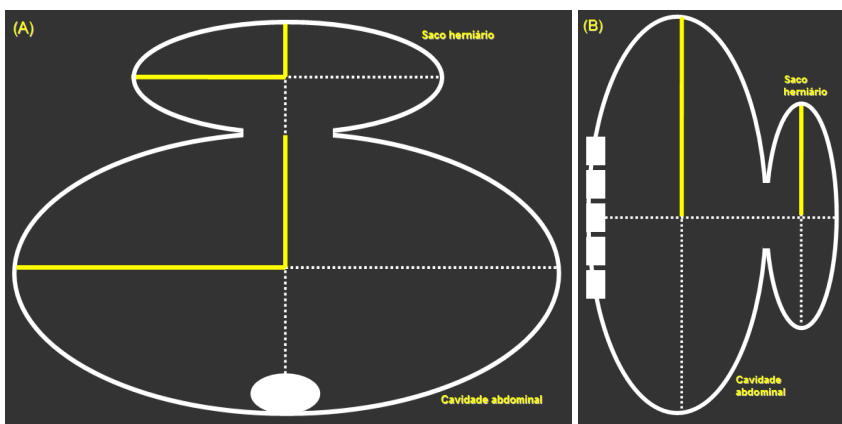

FIGURE 1 - Representation of tomographic sections used to calculate the volume ratio between the abdominal cavity and the hernial sac. The sagittal section (B) provides the third radius required for application of mathematical formula that calculates the volume of each geometric figure with ellipsoid shape

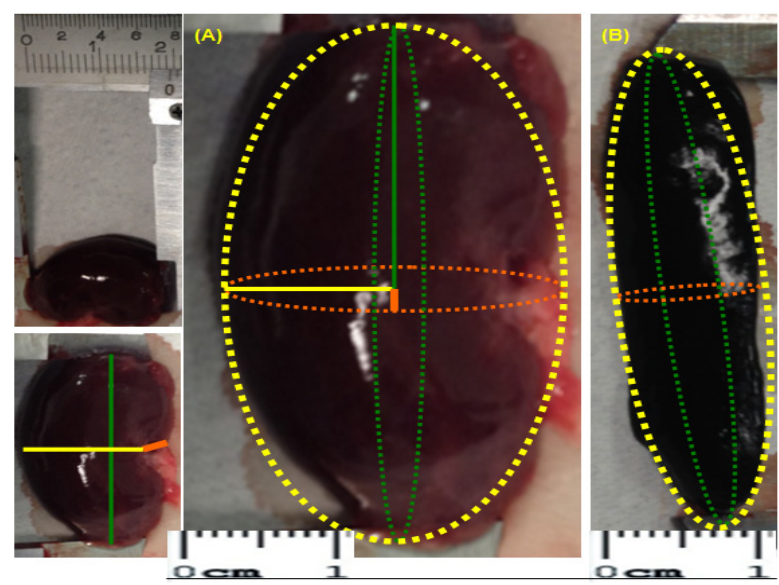

FIGURE 2 - Caliper rule measurements of the left kidney $(A)$ and spleen (B) of rats to obtain the length of the radius $(r 1)$, width ( $r 2)$ and thickness ( $r 3$ ) of each organ allowing to apply the formula to calculate the volume of the ellipsoid: $V=4 / 3 \times \pi \times(r 1 \times r 2 \times r 3)$.

RESULTS

The weight of the organs of ten rats weighing 250-300 g ranged between $0.83 \mathrm{~g}$ and $1.36 \mathrm{~g}$ for the left kidney with an average value of $1.08 \mathrm{~g}$. The spleen weight of these animals varied between $0.21 \mathrm{~g}$ and $0.71 \mathrm{~g}$, with mean $0.51 \mathrm{~g}$.

The mean volume obtained was higher with the direct method, $1.13 \mathrm{~cm}^{3}$ for the left kidney and $0.71 \mathrm{~cm}^{3}$ for the spleen, than the values calculated with the mathematical 
formula of the ellipsoid, $0.81 \mathrm{~cm}^{3}$ and $0.54 \mathrm{~cm}^{3}$ respectively, but there was no statistical significance between the differences of volumes for the two organs $(p>0.05)$ (Table 1$)$.

TABLE 1 - Weight and volume of the left kidney and spleen ten Wistar rats; there was no statistical significance in the comparison between the values of the volume measured directly and calculated specific mathematical formula volume

\begin{tabular}{|c|c|c|c|}
\hline $\begin{array}{l}\text { Weight and } \\
\text { volume }\end{array}$ & Left kidney & Spleen & $\begin{array}{c}\text { Statistic } \\
\text { significance }\end{array}$ \\
\hline \multicolumn{4}{|l|}{ Weight (g) } \\
\hline minimum & 0.83 & 0.21 & \\
\hline maximum & 1.36 & 0.71 & \\
\hline medium & 1.08 & 0.51 & \\
\hline \multicolumn{4}{|l|}{ Volume $\left(\mathrm{cm}^{3}\right)$} \\
\hline minimum & 0.96 & 0.50 & \\
\hline maximum & 1.50 & 0.98 & \\
\hline medium & 1.13 & 0.71 & $p>0.05$ (NS) \\
\hline \multicolumn{4}{|l|}{$\begin{array}{l}\text { Calculated } \\
\text { volume }\left(\mathrm{cm}^{3}\right)\end{array}$} \\
\hline minimum & 0.53 & 0.34 & \\
\hline maximum & 1.50 & 0.94 & \\
\hline medium & 0.81 & 0.54 & $p>0.05$ (NS) \\
\hline
\end{tabular}

\section{DISCUSSION}

Humans are more likely to develop hernias than other animals, but the causes of this condition are still unknown. The abdominal wall hernias, by their frequency and importance, justify some research involving the study of its development and treatment, which basically depends on the mechanisms of tissue healing, allowing various approaches aimed at a research on cellular, molecular and tissue mechanisms of drug action and or non-pharmacological interventions on injury and repair, developed at Universidade Nove de Julho, São Paulo.

Until the first half of the $20^{\text {th }}$ century, it was believed that this disease was caused by mechanical forces, but with the study of connective tissue and its changes, nowadays it is considered that several factors act together. The classic studies of Raymond Read in $1960^{6}$ were the first to call the attention to the weakening of the collagen tissue, a systemic disease where the poor proliferation of fibroblasts produced abnormal collagen and in lower quantity. In the 1980's there was evidence of high proteolytic activity and decreased inhibitory capacity of proteolysis of the blood in patients with hernia ${ }^{6}$. Besides the general surgeon who assesses the alterations of the abdominal wall, such disorders of collagen are also important to vascular surgeons, who treat aortic aneurysm, to gynecologists, who operate the perineal prolapse and digestive surgeons as well, who treat hernias of the esophageal hiatus and perform colon anastomosis ${ }^{7,25}$. These changes can occur in all organs that present a large vascular and internal scaffold that supports the cells, since they are composed of connective tissue such as the colon, skeletal muscle, lungs, liver, heart and eyes.

The group of proteolytic enzymes called matrix metalloproteinases (MMPs) is formed by peptidases responsible for the breakdown of collagen and the collagenases belong to this group. Twenty-eight different MMPs regulated by at least twenty-three genes were identified and are involved in diseases such as skeletal dysplasia, arthritis, cancer, chronic skin ulcers, bronchitis, disorders of the brain, heart and coronary arteries. There is a continual process of synthesis and degradation of collagen fibers in the extracellular matrix, where in case of excessive degradation, the structure of the abdominal wall becomes thinned and its resistance decreases. Metalloproteinases degrade collagen, allowing macrophages and fibroblasts to contribute to tissue repair. This whole process is regulated by tissue inhibitors of metalloproteinases (TIMPs), which limit excessive damage during this degradation. There are collagenases in fibroblasts (MMP-1) and neutrophils (MMP-8, MMP-9), which appear with the inflammatory response and are important during this initial phase of wound healing. Neutrophil proteases, both collagenases and elastases, which seem to act more effectively when tissue destruction occurs, as in periodontal disease, emphysema and aortic aneurysm, a condition that often accompanies inguinal hernia and presents a high risk of developing incisional hernias after its conventional surgical repair ${ }^{6,11}$.

Growth factors are peptides related to tissue repair being released during the inflammatory phase of healing of surgical incisions. Collagen synthesis is inhibited by tumor necrosis factor alpha (TNF- $\alpha$ ), as TGF- $\beta$ (transforming growth factor beta) acts as an enhancer of gene expression of type I collagen, inducing transcription of the COL1A1 gene. Both the formation and the recurrence of the hernia can be seen as a problem related to wound repair and collagenase is released whenever lesions of the basement membrane of the skin occur. The plasmin, and collagenase digest the basement membrane and the extracellular matrix, allowing the growth of new blood vessels in the area of the wound. The abnormal expression of collagenase may be associated with the appearance of hypertrophic and keloid scars, besides interfering with the healing of vascular and chronic diabetic ulcers of leg or foot as well as decubitus or varicose ulcers. These phenomena also explain the invasiveness and production of metastasis that some tumors, particularly of the head and neck, exhibit ${ }^{23}$.

Increased intra-abdominal pressure, age and defects in collagen metabolism are considered risk factors for the formation and recurrence of hernias. Genetic diseases linked to collagen as osteogenesis imperfecta, Marfan's and Ehlers-Danlos syndromes and the polycystic kidneys are also accompanied by a great risk. The high performance athletes, who perform strenuous and repeated activities, are more likely to develop unusual hernias, often difficult to diagnose as the obturator hernias. Weight lifting with large weights is accompanied by significant risk, but moderate physical activity is considered a protective factor for the development of hernias ${ }^{24}$. The effects of an inadequate nutrition, with voluntary restrictive diets (vegetarian exclusive), and vitamin $C$ deficiency are known factors that interfere with collagen synthesis. The intake of toxic substances of leguminous plants in very poor countries in Africa, favoring the appearance of hernias (lathyrism), also illustrates how environmental factors can decisively interfere with it. Smokers have a higher incidence of dehiscence of surgical incisions; Sørensen ${ }^{23}$, studying the operated of digestive system diseases, found a $64 \%$ increased risk of infection and dehiscence $80 \%$ higher in smokers during the first 30 days postoperatively. There is also an increased risk of intestinal anastomotic dehiscence, and scarring of the skin and bones. The appearance of incisional hernias is four times more frequent in these patients, and inguinal hernia may recur more frequently in this group. Smoking induces an increase in oxidative stress, alters the function of neutrophils, affects the formation and degradation of collagen, the function of fibroblasts and macrophages as well. For many years the reduction in tissue oxygenation was considered the main factor to hinder the healing; nicotine induces central and peripheral release of adrenaline that causes vasoconstriction and reduces peripheral blood flow by $40 \%$; carbon monoxide binds to hemoglobin with an affinity 200 times greater than oxygen, reducing its concentration in arterial blood with repercussion in the tissues; arteriosclerosis and chronic lung 
diseases appear more in smokers, complicating the disease. Oxidative stress induced by smoking and the antioxidant effect of vitamin C seem to have an important relationship with the complex mechanisms that interfere with the cicatrization in smokers. Smoking is also considered a risk factor for aortic aneurysms. Such patients have a high incidence of inguinal hernias and their recurrences, besides an incidence close to $30 \%$ for the occurrence of incisional hernias after aneurysm repair, a mutation in the COL3A1 gene was identified, resulting in an alteration of the production of collagen type III, which also occurs in patients with Ehlers-Danlos syndrome ${ }^{20.23}$.

Both obesity and wound infection are also factors for the recurrence of incisional hernias. The effect of aging and higher risk of hernia development in men has not been well defined. The cellular mechanism for the modification of collagen in these situations has not been elucidated. Collagen of skin, tendons and bones progressively decreases each decade of life, as well as its ultrastructure is altered in patients with direct hernia, regardless of the patient's muscles or age; most collagen degradation and increased metalloproteinases appear in the elderly. Healthy premenopausal women have a greater capacity for collagen formation than those that are already in menopause and men, which suggests that the hormones of the reproductive phase of women may explain important aspects of postoperative healing. Regarding the appearance of hernias, genetic and environmental changes are fundamental, interacting with collagen deposition as a true comorbidity and at least 17 genes were identified in this regulation. There is evidence that a single mutation does not occur, but a combination of mutations that would result in defective proteins and cause hernias. Variations in genes of collagen type I and III have not yet been identified in hernias, but the expression of the profile of these genes suggests a change in its transcription ${ }^{7,23}$. The extracellular matrix is in a continual process of synthesis and degradation due to the MMPs, representing an important role in the appearance of hernias. In the fascia of patients with primary or recurrent incisional hernias, the reduction of the rate of collagens I/III as well as a decreased level of MMP-1 and MMP-13, have already been described, justifying multiple lines of research ${ }^{7}$.

The diverticular bowel disease, Crohn's disease and the appearance of fistulas in intestinal anastomosis suggest the presence of a population of genetically defined risk with wound healing disorders. Dehiscence of intestinal anastomoses is a serious complication, and despite the significant development of surgical techniques, the chance of dehiscence of these anastomoses can be higher than $15 \%$ without an adequate explanation for this fact. Studies of the matrix metalloproteinase in the liquid draining of the abdominal cavity showed that the levels of MMPs found can act both, as healing markers and of the development of fistulas in these anastomoses ${ }^{25}$.

Regarding the giant incisional hernias, the proper assessment of "loss of abdominal domain", first described in the $1950 \mathrm{~s}^{13,14}$, is crucial during surgical planning to avoid serious complications, being the calculation of the volume of the hernia sac and abdominal cavity extremely important. In Brazil, the pioneering studies by Kather-Neto and Lázaro da Silva ${ }^{12}$ advocated the calculation of the volume of the hernia sac with tape and pelvimeter, allowing to find the values for calculating the volume of an ellipse. Imaging methods for evaluating the abdominal wall and the abdominal contents in obese have been increasingly used ${ }^{8,9,27}$. Tanaka used in his studies the volume ratio of the sac and cavity, calculated with the aid of CT slices of the abdomen and pelvis, and the mathematical formula of the ellipsoid method which allows you to defining when the hernia is considered giant or when there is loss of domain which asks for the preoperative pneumoperitoneum or even colon resections to achieve the closure of the abdominal cavity, avoiding the abdominal compartment syndrome, a condition of extreme morbidity that may be accompanied by renal and respiratory failure ${ }^{13,14,16,26}$.

Riquena da Silva et al. ${ }^{22}$ studied the spleen volume of rats in an experimental model of pre-hepatic portal hypertension, using the same methodology to calculate the volume of the spleen, which was evaluated in live animals. During the first operation performed, they found an average initial volume of $0.5417 \mathrm{~cm}^{3}$. This study found similar values when spleens were dissected from animal carcasses.

The comparison between the direct method of measuring the volume in cubic centimeters of water with the same volume of mathematical calculation was performed to validate the use of the mathematical formula for calculating the volume of a regular geometric figure, that can be used for the assessment of structures with approximate shape, but not exact, as the hernia sac, kidney and spleen.

\section{CONCLUSIONS}

There was no statistically significant difference between the values of the volume of the kidney and spleen of rats calculated by the direct method of measurement, in centimeters of water displaced by the isolated organ, and the same values calculated with a specific mathematical formula.

\section{REFERENCES}

1. Abdalla RZ, Garcia RB, Costa RID, Abdalla BMZ. Tratamento de hérnias da linha média do abdome com uso de grampeador endoscópico para fechamento da linha média. Arq Bras Cir Dig 2013;26(4):335-7.

2. Abdalla RZ, Averbach $M$, Ribeiro-Júnior $U$, Machado MAC, De Luca-Filho CRP. Cirurgia abdominal por robótica: experiência brasileira inicial. Arq Bras Cir Dig 2013;26(3):190-4.

3. Ball CG, Kirkpatrick AW, McBeth P. The secondary abdominal compartment syndrome: not just another post-traumatic complication. Can J Surg 2008; 51(5): 399-405.

4. Barbuto RC, Duval-Araujo I, Barral SM, Rocha RG, Bechara CS, Barbosa AJA. Uso de telas inorgânicas em feridas abdominais de ratos com peritonite induzida. Arq Bras Cir Dig 2014;27(1):26-9.

5. Burch JM, Moore EE, Moore FA, Franciose R. The abdominal compartment syndrome. Surg Clin North Am 1996;76(4):833-42.

6. Donahue TR, Hiatt JR, Busuttil RW. Collagenase and surgical disease. Hernia 2006;10(6):478-85.

7. El Sherif A, Yano F, Mittal S, Filipi CJ. Collagen metabolism and recurrent hiatal hernia: cause and effect? Hernia 2006;10(6):511-20.

8. Emby DJ, Aoun G. CT technique for suspected anterior abdominal wall hernia. AJR 2003;181:431-3.

9. Gouvêa HR, Faria SL, Faria OP, Cardeal MA, Bezerra A, Ito MK. Validação da ultrassonografia para a avaliação da gordura abdominal visceral em obesos clinicamente graves. Arq Bras Cir Dig 2013;26(suplemento):43-6.

10. Hassan AZ, Kadima KB, Remi-adewumi BD, Awasum CA, Abubakar MT. Animal models in surgical training: choise and ethics. Nigerian J Surg Res. 2005; 7: 260-7.

11. Jansen PL, Klinge $U$, Mertens PR. Hernia disease and collagen regulation: are there clues for intervention? Hernia 2006;10(6):486-91.

12. Kather-Neto JM, Lázaro da Silva A. Cálculo de volume do saco herniário na hérnia incisional longitudinal no pré-operatório e sua aplicação no planejamento cirúrgico. Rev Bras Cir 1991;81(3):129-35.

13. Kingsnorth AN, Sivarajasingham N, Wong S, Butler M. Open mesh repair of incisional hernias with significant loss of domain. Ann $R$ Coll Surg Engl 2004;86: 363-6.

14. Kingsnorth AN. The management of incisional hernia. Ann R Coll Surg Engl 2006;88(3): 252-60.

15. Kinshoku MR, Rodriguez CAL, Fidalgo RS, Duran CCG, Leme PLS, Duarte IS. Uso racional de modelos animais para pesquisa e ensino de microcirurgia. Rev Col Bras Cir 2012;39(5):414-417.

16. Koontz AR, Graves JWV. Preoperative pneumoperitoneum as an aid in the handling of gigantic hernias. Ann Surg 1954; 140(5): 759-62.

17. Kron IL, Harman PK, Nolan SP. The measurement of intra- 
abdominal pressure as a criterion for abdominal re-exploration. Ann Surg 1984; 199(1):28-30.

18. Leme PLS, Carvalho DLM, Salinas JA, Bove CR, Höhne OMP, Viana AT. Hérnias incisionais: análise de 143 doentes operados. Arq Med Hosp Fac Ciên Méd S Casa SP 2005; 50: 41-5.

19. Leme PLS, Turatti RC. Tratamento operatório das hérnias incisionais com videocirurgia, a morbidade e mortalidade são aceitáveis? Rev Assoc Med Bras 2010; 56: 2.

20. Leme PLS, Turatti RC. Quem fuma tem mais chance de apresentar hérnia inguinal? Rev Assoc Med Bras 2010; 56: 3.

21. Shell IV DH, de la Torre J, Andrades P, Vasconez LO. Open repair of ventral incisional hernias. Surg Clin N Am 2008;88:61-83.

22. Silva AR, Kriguer-Júnior RJ, Serigiolle LC, Gomes HMP, Rodrigues $D A B$, Leme PLS. Increase in spleen volume of rats on experimental model of pre-hepatic portal hypertension. Arq Bras Cir Dig 2013;26(3):206-212.

23. Sørensen LT. Effect of lifestyle, gender and age on collagen formation and degradation. Hernia 2006;10(6): 456-81.

24. Sperandio WT, Queroz T, Soares RP, Kelmann G, Bernardo WM. Quais os fatores de risco para hérnia inguinal em adulto? Rev Assoc Med Bras 2008; 54(2): 98.

25. Stumpf M, Krones CJ, Klinge U, Rosch R, Junge K, Schumpelick V. Collagen in colon disease. Hernia 2006; 10(6): 498-501.

26. Tanaka EY, Yoo JH, Rodrigues-Júnior AJ, Utiyama EM, Birolini $D_{\text {, }}$ Rasslan S. A computerized tomography scan method for calculating the hernia sac and abdominal cavity volume in complex large incisional hernia with loss of domain. Hernia 2010;14(1):63-9.

27. Turatti RC, Moura VM, Cabral RH, Simionato-Neto D, Sevillano MM, Leme PLS. Sonographic aspects and anatomy of the aponeurosis of transversus abdominis muscle. Arq Bras Cir Dig 2013;26:184-9. 